\title{
Relevansi Agama dan Kemiskinan; \\ Upaya Memahami Kemiskinan Secara Multidimensional dan Solusi yang Ditawarkan dalam Ekonomi Islam*
}

(Relevance of Religion and Poverty; Efforts to Understand Poverty Multidimensionally and Solutions Offered in Islamic Economics)

\author{
Melis ${ }^{1}$ \\ FEBI Universitas Islam Negeri Raden Fatah, Palembang, Indonesia \\ doi $10.15408 /$ sjsbs.v6i2.11227
}

\begin{abstract}
Islam has warned its people not to be unemployed so that it slips into poverty, because it is feared that with poverty someone will do anything, including harming others to meet their needs. There is a hadith which says "Poverty will bring closer to disbelief." The fact shows that the unemployment rate in a country with a majority Muslim population is relatively high. Increasing people's understanding of unemployment as a bad thing, both for individuals, society and the state will increase motivation to work more seriously. Even though God promises to bear our sustenance, it does not mean without any conditions that need to be fulfilled. The most important requirement is to try to find the promised sustenance, because Almighty God has created a "system" that is whoever works will get sustenance and whoever sits will lose fortune. That is, there is a process that must be passed to get sustenance.
\end{abstract}

Keywords: Religion, Poverty, Solutions, Islamic Economy

\begin{abstract}
Abstrak
Islam telah memperingatkan umatnya agar tidak menganggur sehingga tergelincir ke jurang kemiskinan, karena dikhawatirkan dengan kemiskinan seseorang akan melakukan apa saja, termasuk merugikan orang lain demi memenuhi kebutuhan dirinya. Ada sebuah hadis yang mengatakan "Kemiskinan akan membawa lebih dekat kepada kekafiran." Fakta menunjukkan bahwa tingkat pengangguran di negara yang berpopulasi mayoritas muslim relatif tinggi. Meningkatnya pemahaman masyarakat tentang pengangguran sebagai hal yang buruk, baik bagi individu, masyarakat maupun negara akan meningkatkan motivasi untuk bekerja lebih serius. Meskipun Tuhan berjanji untuk menanggung rezeki kita semua, tetapi itu tidak berarti tanpa persyaratan apa pun yang perlu dipenuhi. Syarat yang paling penting adalah harus berusaha menemukan rezeki yang dijanjikan itu, karena Tuhan Yang Mahakuasa telah menciptakan "sistem" yaitu siapapun yang bekerja maka akan mendapatkan rezeki dan siapa pun yang duduk maka akan kehilangan rezeki. Artinya, ada proses yang harus dilalui untuk mendapatkan rezeki.
\end{abstract}

Kata kunci: Agama, Kemiskinan, Solusi, Ekonomi Islam

\footnotetext{
* Diterima: 24 Desember 2018, Revisi: 22 Februari 2019, Dipublikasi 1 Mei 2019.

1 Melis adalah dosen tetap FEBI Universitas Islam Negeri Raden Fatah, Palembang, Indonesia. E-mail: mgirl498@gmail.com.
} 


\section{Pendahuluan}

Agama secara inheren memiliki nilai-nilai emansipasi, karena itu dalam sejarah agama telah menempatkan dirinya sebagai penggerak perubahan. Dalam konteks Indonesia, ketertinggalan yang berarti kemiskinan merupakan tantangan yang harus diatasi dengan partisipasi dan keberpihakan agama, karena dari komposisi masyarakat Indonesia dikenal sebagai masyarakat yang religius. Namun potensinya belum tergali secara signifikan guna membebaskan masyarakat dari berbagai masalah.

Sebagai bangsa yang religius, kita perlu berpikir serius tentang tanggung jawab moral-sosial terkait apa yang dihadapi bangsa ini. Agama dengan iman dan kepercayaannya diharapkan ada pada garda terdepan perubahan sosial dan perbaikan derajat hidup dan kehidupan umatnya. Mungkin tidak berlebihan menempatkan nilai-nilai iman yang emansipatif menjadi obor penerang ritual sosial yang membangkitkan bangsa. Pada batasnya, tugas mulia hadirnya agama adalah untuk membangkitkan umat dari ketertinggalan. Ketertinggalan yang berarti kemiskinan dalam Islam dianggap sebagai persoalan serius sekaligus berbahaya, karena kemiskinan terkadang menjadikan tingkat keimanan menjadi terganggu dan justru dikhawatirkan hilang atau dengan kata lain menjadi kafir.

Kemiskinan adalah fenomena yang begitu mudah dijumpai di mana-mana. Tidak hanya di desa-desa, namun juga di kota-kota. Di balik kemewahan gedung-gedung pencakar langit di kota, misalnya, tidak terlalu sulit dijumpai rumah-rumah kumuh berderet di bantaran sungai, atau para pengemis yang berkeliaran di perempatan-perempatan jalan. Berbagai program sudah dilakukan untuk mengatasi persoalan sosial tersebut, tetapi anehnya, secara statistik jumlah mereka bukan berkurang, tetapi justru semakin bertambah. Terlebih lagi setelah krisis ekonomi melanda Indonesia. ${ }^{2}$

Pada dekade terakhir ini, kemiskinan menjadi topik yang dibahas dan diperdebatkan di berbagai forum nasional dan internasional, walaupun kemiskinan itu sendiri telah muncul ratusan tahun yang lalu. Fakta menunjukkan pembangunan yang telah dilakukan belum mampu meredam meningkatnya jumlah penduduk miskin di dunia, khususnya negara-negara berkembang.

Diperkirakan ada yang kurang tepat dalam mamahami dan merumuskan serta implementasi kebijakan untuk memberantas kemiskinan dan memberdayakan penduduk miskin. Selama ini kemiskinan lebih sering dikaitkan dengan dimensi ekonomi karena dimensi inilah yang paling mudah diamati,

2 Data tentang kemiskinan di Indonesia dapat disampaikan sebagai berikut : Jumlah penduduk miskin (penduduk yang berada dibawah Garis Kemiskinan) di Indonesia pada bulan September 2015 sebesar 28,51 juta (11,13 persen). Dibandingkan dengan penduduk miskin pada September 2016 yang berjumlah 27,76 juta (10,70 persen), berarti jumlah penduduk miskin mengalami penurunan sebesar 0,43 persen. (Sumber: bps.go.oid) 
diukur, dan diperbandingkan. Padahal kemiskinan berkaitan juga dengan berbagai dimensi lainnya, antara lain dimensi sosial, budaya, sosial politik, lingkungan (alam dan geografis), kesehatan, pendidikan, agama, dan budi pekerti. Menelaah kemiskinan secara multidimensional sangat diperlukan untuk memahami secara komprehensip sebagai pertimbangan perumusan kebijakan pengentasan kemiskinan.

Naskah ini mencoba menelaah kemiskinan dari segi normatif tekstual, baik menurut konsep agama (Islam) maupun teori yang dikembangkan para pakar, dan dari segi empiris kontektual, yaitu mencoba memahami hasil-hali penelitian yang dilakukan oleh berbagai pihak.

\section{Kemiskinan dari Segi Normatif Tekstual}

Konsep tentang kemiskinan sangat beragam, mulai dari sekadar ketidakmampuan memenuhi kebutuhan konsumsi dasar dan memperbaiki keadaan, kurangnya kesempatan berusaha, hingga pengertian yang lebih luas yang memasukkan aspek sosial dan moral. Misalnya, ada pendapat yang mengatakan bahwa kemiskinan terkait dengan sikap, budaya hidup, dan lingkungan dalam suatu masyarakat atau yang mengatakan bahwa kemiskinan merupakan ketakberdayaan sekelompok masyarakat terhadap sistem yang diterapkan oleh suatu pemerintahan sehingga mereka berada pada posisi yang sangat lemah dan tereksploitasi (kemiskinan struktural). Tetapi pada umumnya, ketika orang berbicara tentang kemiskinan, yang dimaksud adalah kemiskinan material.

Dengan pengertian ini, maka seseorang masuk dalam kategori miskin apabila tidak mampu memenuhi standar minimum kebutuhan pokok untuk dapat hidup secara layak. Ini yang sering disebut dengan kemiskinan konsumsitif. Memang definisi ini sangat bermanfaat untuk mempermudah membuat indikator orang miskin, tetapi definisi ini sangat kurang memadai karena; (1) tidak cukup untuk memahami realitas kemiskinan; (2) dapat menjerumuskan ke kesimpulan yang salah bahwa menanggulangi kemiskinan cukup hanya dengan menyediakan bahan makanan yang memadai; (3) tidak bermanfaat bagi pengambil keputusan ketika harus merumuskan kebijakan lintas sektor, bahkan bisa kontraproduktif.

\section{Konsep Kemiskinan Perspektif Agama}

a. Pengertian Kemiskinan

Kemiskinan adalah akar kata dari miskin dengan awalan ke dan akhiran an yang menurut kamus bahasa Indonesia mempunyai persamaan arti dengan kefakiran yang berasal dari asal kata fakir dengan awalan ke dan akhiran an. Dua 
kata tersebut seringkali juga disebutkan secara bergandengan; fakir miskin dengan pengertian orang yang sangat kekurangan. ${ }^{3}$ Al-Qur'an memakai beberapa kata dalam menggambarkan kemiskinan, yaitu faqir, miskin, al-sail, dan al-mahrum, tetapi dua kata yang pertama paling banyak disebutkan dalam ayat al-Qur'an. Kata fakir dijumpa dalam al-Qur'an sebanyak 12 kali dan kata miskin disebut sebanyak 25 kali, $^{4}$ yang masing-masing digunakan untuk pengertian yang bermacam-macam.

Tentang dua golongan yang pertama; fakir dan miskin para ahli berbeda pendapat, ada yang mengatakan bahwa dua golongan tersebut pada hakikatnya adalah sama. Demikian pendapat Abu Yusuf, pengikut Imam Abu Hanifah dan Ibnu Qasim pengikut Imam Malik. ${ }^{5}$ Berbeda dengan pendapat sebagian besar ulama, sebenarnya keduanya adalah dua golongan tetapi satu macam, yakni dalam hal kondisi kekurangan dan dalam kebutuhan. Para ahli tafsir dan ahli fikih juga berbeda pendapat dalam memberi definisi kedua kata tersebut. Yusuf Qardawi memberikan perumpamaan bahwa kedua kata tersebut seperti Islam dan Iman, kalau dikumpulkan terpisah, yakni masing-masing mempunyai arti tersendiri, dan jika dipisah terkumpul, yakni bila salah satu disebutkan sendirisendiri, masing-masing mempunyai arti buat kata lain yang sejajar. ${ }^{6}$

Raqib al-Isfahani (w. 502 H/1108 M)7[7], ahli fikih dan ahli tafsir, menyebutkan empat macam pengertian fakir. Pertama, fakir dalam arti orang yang memerlukan kebutuhan hidup yang primer, yaitu makanan, minuman,

\footnotetext{
${ }^{3}$ Dua kata : "fakir dan miskin" menurut kamus bahasa Indonesia sebenarnya mempunyai arti yang berbeda, fakir mempunyai dua pengertian; yaitu 1) orang yang sangat kekurangan; orang yang terlalu miskin. 2) orang yang sengaja membuat dirinya menderita kekurangan untuk mencapai kesempurnaan batin. Sedangkan miskin juga mempunyai pengertian; 1) tidak berharta benda, serba kekurangan, berpenghasilan rendah. Lihat Lukman Ali et.all., Kamus Besar Bahasa Indonesia, Edisi Kedua, Cetakan Ketujuh (Jakarta: Balai Pustaka, 1996), 273 dan 660.
}

${ }^{5}$ Yusuf Qardawi, Hukum Zakat, Cetakan keenam (Jakarta: Litera AntarNusa, 2002), 511.

${ }^{6}$ Orientalis Josef Schacht dalam Ensiklopedi Islam mengatakan : “Perbedaan antara kata "fakir dan miskin" ialah perbedaan yang dipaksa-paksa dalam segala seginya. Para ulama fikih biasanya suku menafsirkan suatu definisi dan ${ }^{6}$ Dua kata : "fakir dan miskin" menurut kamus bahasa Indonesia sebenarnya mempunyai arti yang berbeda, fakir mempunyai dua pengertian; yaitu 1) orang yang sangat kekurangan; orang yang terlalu miskin. 2) orang yang sengaja membuat dirinya menderita kekurangan untuk mencapai kesempurnaan batin. Sedangkan miskin juga mempunyai pengertian; 1) tidak berharta benda, serba kekurangan, berpenghasilan rendah. Lihat Lukman Ali et.all., Kamus Besar Bahasa Indonesia, Edisi Kedua, Cetakan Ketujuh (Jakarta: Balai Pustaka, 1996), 273 dan 660.

${ }^{6}$ Yusuf Qardawi, Hukum Zakat sering memasukkan diri mereka sendiri ke dalam salah satu kelompok itu." Selanjutnya Yusuf Qardawi mengatakan sebagai umpan balik pernyataan Josef Schacht; kalau orang mempunyai sedikit saja etika kesarjanaan tidak akan mengeluarkan pernyataan kosong semacam itu. Lihat Yusuf Qardawi, Ibid. 512.

${ }^{7}$ Al-Raghib al-Ashfahaniy, Mu'jam Mufradat Alfazh al-Qur'an (Beirut: Dar al-Fkr, tanpa tahun), 397-398. 
tempat tinggal, dan keamanan. Kedua, fakir dalam arti orang yang tidak dapat memenuhi kebutuhan hidupnya yang primer, tetapi ia dapat menjaga dirinya dari meminta-minta. Ketiga, fakir dalam arti fakir jiwanya. Ini termasuk golongan fakir yang paling buruk karena dapat mendorong orang itu kepada kekafiran. Keempat, fakir dalam arti orang yang selalu merasa butuh kepada petunjuk dan bimbingan Tuhan, sehingga orang tersebut tidak merasa sombong.

Pengertian fakir selanjutnya dibahas dalam ilmu fikih. Sayid Sabiq ${ }^{8}$, ahli fikih dari Mesir, mengatakan bahwa yang tergolong orang fakir adalah orang yang tidak memiliki harta sebanyak satu nisab (sejumlah minimal harta kekayaan yang harus dikeluarkan zakatnya dalam waktu tertentu). Menurut Imam Abu Hanifah ${ }^{9}$, fakir adalah orang yang mempunyai harta kurang dari satu nisab atau mempunyai harta satu nisab atau lebih tetapi habis digunakan untuk memenuhi kebutuhan hidupnya.

Sebagaimana kata fakir, kata miskin pun mengalami pengertian yang bermacam-macam. Imam Abu Hanifah dan Imam Malik mengatakan bahwa orang miskin adalah orang yang memiliki harta setengah dari kebutuhan hidupnya atau lebih tetapi tidak mencukupi.

Dari segi kekurangan harta yang dimilikinya dan kedudukannya sebagai salah satu penerima zakat tampak ada perbedaan. Sayid Sabiq ${ }^{10}$ mengatakan bahwa fakir miskin disebut secara bersamaan dengan menggunakan huruf waw al'ataf (kata sambung), sebagaimana dijumpai dalam surat at-Taubah (9) ayat 60, menunjukkan bahwa miskin adalah bagian dari fakir, atau orang miskin itu pada hakekatnya adalah orang fakir juga, tetapi ia memiliki ciri-ciri yang khusus. Dalam hadis Nabi SAW dijelaskan bahwa di antara ciri-ciri orang miskin itu adalah orang fakir yang enggan meminta-minta kepada orang lain: "Orang miskin itu bukanlah orang yang engkau berikan sebutir atau dua butir kurma, sesuap atau dua suap makanan, melainkan orang miskin itu adalah orang yang memilihara dirinya dari meminta-minta" (HR. Abu Dawud) ${ }^{11}$.

\section{b. Faktor dan Indikator Kemiskinan}

Menurut KH. Ali Yafie ${ }^{12}$ terdapat petunjuk dari salah satu hadis yang mengungkapkan sebab-sebab kemiskinan, yang berbunyi:

\footnotetext{
${ }^{8}$ Sayid Sabiq, Fikih Sunnah, Jilid I, Cetakan keempat (Bairut Lebanon: Dar al-Fikr, 1983 M/1403 H), 324-325.

${ }^{9}$ Wahbah al-Zuhayli, al-Figh al-Islami wa Adillatuh, Cetakan keempat (Bairut Lebanon: Dar alFikr, 1997 M/1418 H), 1953. dan Abd. Rahman bin Muhammad 'Awadl al-Jaziriy, al-Figh 'ala Madzahib al-'Arba'ah (Mesir: Dar Ibn al-Haitsam, tanpa tahun), 349.

${ }^{10}$ Sayid Sabiq, Loc. Cit.
}

${ }^{12}$ Ali Yafie, "Islam Dan Problema Kemiskinan ," Majalah Pesantren, No.2/VolIII/1986, 3. 
"... aku mohon supaya Engkau (Tuhan) melindungi aku dari kelemahan (al-'ajz), kemalasan, ketakutan, kepelitan, terlilit hutang dan diperas atau dikuasai sesama manusia."

Di dalamnya tercantum hal-hal pokok yang menimbulkan kemiskinan yang memelaratkan, yaitu:

Pertama: Kelemahan. Apakah itu kelemahan hati dan semangat, atau kelemahan akal dan ilmu, ataukah kelemahan fisik. Semua itu mengurangi daya pilih dan daya upaya manusia sehingga tidak mampu menjalankan fungsinya sebagai pencipta dan pembangun untuk memenuhi kebutuhan hidupnya.

Kedua: Kemalasan. Tidak diragukan lagi bahwa sifat ini merupakan pangkal utama dari kemiskinan. Penataan hidup sehari-hari yang diajarkan oleh Islam sangat bertolak belakang dengan sifat ini.

Ketiga: Ketakutan. Hal ini pun jelas merupakan penghambat utama untuk mencapai suatu sukses dalam pekerjaan dan usaha. Keberhasilan seseorang dalam merintis ataupun melanjutkan sesuatu atau tugas banyak tergantung dari keberanian yang ada pada dirinya.

Keempat: Kepelitan. Hal ini banyak bersangkutan dengan pihak si kaya, karena dengan sifat ini tanpa disadari kepelitannya itu membantu untuk tidak mengurangi kemiskinan, dan menempatkan dirinya menjadi sasaran untuk dibenci oleh si miskin.

Kelima: Terlilit hutang. Terdapat banyak peringatan dari ajaran Islam untuk berhati-hati jangan sampai terjerat hutang-utang, karena hutang itu adalah sangat membelenggu kebebasan, baik di dunia maupun di akhirat. Apalagi orang yang sudah terbiasa dengan membiayai hidupnya dari hutang-hutang sulit sekali mengangkat dirinya dari lumpur kemiskinan.

Keenam: Diperas atau dikuasai sesama manusia. Hal ini merupakan penyebab bagi timbulnya banyak penderitaan dan kemelaratan, baik pada tingkat perorangan maupun pada tingkat masyarakat, bangsa dan negara. Pemerasan manusia kuat menimbulkan sistem perbudakan, dan pemerasan manusia kaya menimbulkan sistem riba. Dan pemerasan pada tingkat masyarakat bangsa/negara menimbulkan sistem kapitalisme yang berkembang menjadi imperialisme. Kenyataan yang ada di negeri-negeri jajahan atau setengah jajahan membuktikan dengan jelas betapa besar kemiskinan yang memelaratkan masyarakat, berabad-abad lamanya sebagai akibat langsung dari sistem imperialisme itu.

\section{c. Pemberdayaan dan Solusi Kemiskinan dalam Ekonomi Islam}

Allah SWT sesungguhnya telah menciptakan manusia, sekaligus menyediakan sarana-sarana untuk memenuhi kebutuhannya. Bahkan tidak 
hanya manusia; seluruh makhluk yang telah, sedang, dan akan diciptakan, pasti Allah menyediakan rizki baginya. Tidaklah mungkin, Allah menciptakan berbagai makhluk, lalu membiarkan begitu saja tanpa menyediakan rizki bagi mereka (Qs. ar-Rûm [30]: 40) dan (Qs. Hûd [11]: 6).

Islam adalah sistem hidup yang shahih. Islam memiliki cara yang khas dalam menyelesaikan masalah kemiskinan. Syariat Islam memiliki banyak hukum yang berkaitan dengan pemecahan masalah kemiskinan; baik kemiskinan alamiyah, kultural, maupun sruktural. Hanya saja, hukum-hukum itu tidak berdiri sendiri, melainkan memiliki hubungan sinergis dengan hukumhukum lainnya. Jadi, dalam menyelesaikan setiap masalah, termasuk kemiskinan, Islam menggunakan pendekatan yang bersifat terpadu. Bagaimana Islam mengatasi kemiskinan, dapat dijelaskan sebagai berikut:

\section{Jaminan Pemenuhan Kebutuhan Primer}

Islam telah menetapkan kebutuhan primer manusia terdiri dari pangan, sandang, dan papan. Terpenuhi-tidaknya ketiga kebutuhan tersebut selanjutnya menjadi penentu miskin-tidaknya seseorang. Sebagai kebutuhan primer, tentu pemenuhannya atas setiap individu, tidak dapat ditawar-tawar lagi. Oleh karena itu, Islam memberikan jaminan atas pemenuhan kebutuhan ini.

\section{Pengaturan Kepemilikan}

Pengaturan kepemilikan memiliki hubungan yang sangat erat dengan masalah kemiskinan dan upaya untuk mengatasinya. Syariat Islam telah mengatur masalah kepemilikan ini, sedemikian rupa sehingga dapat mencegah munculnya masalah kemiskinan. Bahkan, pengaturan kepemilikan dalam Islam, memungkinkan masalah kemiskinan dapat diatasi dengan sangat mudah.

\section{Penyediaan Lapangan Kerja}

Menyediakan lapangan pekerjaan merupakan kewajiban negara. Hal ini menyandar pada keumuman hadits Rasululah Saw. ${ }^{13}$

Dalam sebuah riwayat diceritakan bahwa Rasulullah Saw pernah memberikan dua dirham kepada seseorang. Kemudian Beliau Saw bersabda:

"Makanlah dengan satu dirham, sisanya belikan kapak, lalu gunakan ia untuk bekerja."

\section{Penyediaan Layanan Pendidikan}

${ }^{13}$ Hadis tersebut dapat dilihat di Shahih al-Bukhari; 844, Shahih Muslim; 3408 Sunan alTurmudzi; 1627, Sunan Abu Dawud; 2539, Sunan Ibn Majah; 2829, Musnad Ahmad; 4266, 4920, 5603, 5635, 5753. Lihat Masu'ah al-Hadis al-Syarif, Cetakan kedua, 2000 (Jami' al-Huquq Mahfudlah li Syirkah al-Baramij al-Islamiyah al-Dauliyah (Global IslamicSoftware Company), 1991-1997). 
Syariat Islam telah mewajibkan negara untuk menyediakan layanan pendidikan secara cuma-cuma kepada rakyat. Sebab, pendidikan memang merupakan kebutuhan dasar bagi setiap individu rakyat. Layanan pendidikan ini akan meningkatkan kualitas sumberdaya manusia, dan selanjutnya akan mewujudkan individu-individu yang kreatif, onovatif, dan produktif. Dengan demkian kemiskinan kultural akan dapat teratasi.

\section{Konsep Kemiskinan Perspektif Para Pakar}

\section{a. Pengertian Kemiskinan}

Dalam arti proper kemiskinan dipahami sebagai keadaan kekurangan uang dan barang untuk menjamin kelangsungan hidup. Dalam arti luas, kemiskinan merupakan suatu fenomena multi face atau multidimensional. ${ }^{14}$

Chambers (dalam Nasikun $)^{15}$ mengatakan bahwa kemiskinan adalah suatu integrated concept yang memiliki lima dimensi, yaitu: 1) kemiskinan (proper), 2) ketidakberdayaan (powerless), 3) kerentanan menghadapi situasi darurat (state of emergency), 4) ketergantungan (dependence), dan 5) keterasingan ( isolation) baik secara geografis maupun sosiologis.

\section{b. Indikator dan Faktor Kemiskinan}

Indikator utama kemiskinan adalah; (1) terbatasnya kecukupan dan mutu pangan; (2) terbatasnya akses dan rendahnya mutu layanan kesehatan; (3) terbatasnya akses dan rendahnya mutu layanan pendidikan; (4) terbatasnya kesempatan kerja dan berusaha; (5) lemahnya perlindungan terhadap aset usaha, dan perbedaan upah; (6) terbatasnya akses layanan perumahan dan sanitasi; (7) terbatasnya akses terhadap air bersih; (8) lemahnya kepastian kepemilikan dan penguasaan tanah; (9) memburuknya kondisi lingkungan hidup dan sumberdaya alam, serta terbatasnya akses masyarakat terhadap sumber daya alam; (10) lemahnya jaminan rasa aman; (11) lemahnya partisipasi; (12) besarnya beban kependudukan yang disebabkan oleh besarnya tanggungan keluarga; (13) tata kelola pemerintahan yang buruk yang menyebabkan inefisiensi dan inefektivitas dalam pelayanan publik, meluasnya korupsi dan rendahnya jaminan sosial terhadap masyarakat.

Nasikun ${ }^{16}$ menyoroti beberapa sumber dan proses penyebab terjadinya kemiskinan, yaitu:

${ }^{14}$ Nasikun. Diktat Mata Kuliah. Isu dan Kebijakan Penanggulangan Kemiskinan. Magister Administrasi Publik. Universitas Gadjah Mada, Yogyakarta. 2001.

${ }^{16}$ Nasikun. Diktat Mata Kuliah. Isu dan Kebijakan Penanggulangan Kemiskinan. Magister Administrasi Publik. Universitas Gadjah Mada, Yogyakarta. 2001. 
a. Policy induces processes: proses pemiskinan yang dilestarikan, direproduksi melalui pelaksanaan suatu kebijakan (induced of policy) diantaranya adalah kebijakan antikemiskinan, tetapi realitanya justru melestarikan.

b. Socio-economic dualism: negara ekskoloni mengalami kemiskinan karena pola produksi kolonial, yaitu petani menjadi marjinal karena tanah yang paling subur dikuasai petani skala besar dan berorientasi ekspor.

c. Population growth: perspektif yang didasari pada teori Malthus bahwa pertambahan penduduk seperti deret ukur sedang pertambahan pangan seperti deret hitung.

d. Recources management and the environment: adanya unsur mismanagement sumber daya alam dan lingkungan, seperti manajemen pertanian yang asal tebang akan menurunkan produktivitas.

e. Natural cycles and processes: kemiskinan terjadi karena siklus alam. Misalnya tinggal di lahan kritis, di mana lahan ini jika turun hujan akan terjadi banjir tetapi jika musim kemarau akan kekurangan air, sehingga tidak memungkinkan produktivitas yang maksimal dan terus-menerus.

f. The marginalization of woman: peminggiran kaum perempuan karena perempuan masih dianggap sebagai golongan kelas kedua, sehingga akses dan penghargaan hasil kerja yang diberikan lebih rendah dari laki-laki.

g. Cultural and ethnic factors: bekerjanya faktor budaya dan etnik yang memelihara kemiskinan. Misalnya, pola hidup konsumtif pada petani dan nelayan ketika panen raya, serta adat istiadat yang konsumtif saat upacara adat atau keagamaan.

h. Explotative intermediation: keberadaan penolong yang menjadi penodong, seperti rentenir (lintah darat).

i. Internal political fragmentation and civil stratfe: suatu kebijakan yang diterapkan pada suatu daerah yang fragmentasi politiknya kuat, dapat menjadi penyebab kemiskinan.

j. International processes: bekerjanya sistem-sistem internasional (kolonialisme dan kapitalisme) membuat banyak negara menjadi semakin miskin.

\section{c. Pemberdayaan dan Pengentasan Kemiskinan}

Menurut Gregorius Sahdan ${ }^{17}$, selama ini kebijakan penanggulangan kemiskinan, didesain secara sentralistik oleh pemerintah pusat yang diwakili BAPPENAS. BAPPENAS merancang program penangulangan kemiskinan

17 Gregorius Sahdan, Menanggulangi Kemiskinan Desa, www.ekonomirakyat.org, Jurnal Ekonomi Rakyat. 
dengan dukungan alokasi dan distribusi anggaran dari APBN (Anggaran Pendapatan dan Belanja Negara) dan utang kepada Bank Dunia serta lembaga keuangan multinasional lainnya.

Dari serangkaian penyebab kemiskinan masyarakat desa yang telah disebutkan di atas, maka strategi dan kebijakan alternatif menanggulangi kemiskinan desa dapat dilakukan dengan cara;

(1) Memberikan kesempatan yang luas kepada masyarakat desa untuk memperoleh layanan pendidikan yang memadai, secara gratis dan cumacuma. Pemerintah perlu mengembangkan sistem pendidikan nasional yang berorentasi keberpihakan kepada orang miskin (pendidikan untuk orang miskin).

(2) Redistribusi lahan dan modal pertanian yang seimbang. Ketimpangan kepemilikan lahan pertanian, memperlebar jurang kemiskinan antara masyarakat yang tinggal di pedesaan. Sebagian besar tanah-tanah pertanian yang subur dimiliki oleh tengkulak lokal dan tuan tanah.

(3) Mendorong perkembangan investasi pertanian dan pertambangan ke daerah pedesaan. Pembukaan investasi pertanian dan pertambangan dapat memberikan kesempatan kerja kepada masyarakat desa. Dengan begitu, pendapatan mereka akan meningkat dan berpengaruh pada perubahan kesejahteraan hidup;

(4) Membuka kesempatan yang luas kepada masyarakat desa untuk memperoleh kredit usaha yang mudah.

(5) Memenuhi kebutuhan sandang, pangan, dan papan masyarakat desa. Kebutuhan sandang, papan dan pangan perlu dilakukan melalui sebuah mekanisme lumbung desa yang memberikan kesempatan yang sama kepada masyarakat desa, memperoleh sumber-sumber kebutuhan yang disediakan secara terorganisir;

(6) Memperkenalkan sistem pertanian modern dengan teknologi baru yang memberikan kemudahan bagi masyarakat untuk menggali sumber-sumber pendapatan yang memadai. Teknologi pertanian diperbanyak dan diberikan secara cuma-cuma kepada petani untuk meningkatkan produktivitas pertanian dan mempermudah pemenuhan kebutuhan hidup mereka;

(7) Memberikan jaminan kesehatan kepada mayarakat dengan sistem layanan kesehatan gratis, memperbanyak PUSKESMAS dan unit-unit layanan kesehatan kepada masyarakat desa yang miskin dan terbelakang;

(8) Memberikan jaminan asuransi dan jaminan sosial terhadap masyarakat desa. Jaminan asuransi dan jaminan sosial dapat meningkatkan kualitas hidup masyarakat miskin dan memberikan semangat hidup yang lebih 
berarti. Sistem asuransi dan jaminan sosial yang ada saat ini, diberlakukan secara diskriminatif, hanya terbatas kepada mereka yang memiliki uang saja. Untuk itu, pemerintah berkewajiban memberikan jaminan asuransi yang memadai kepada masyarakat miskin;

(9) Memperkuat komitmen eksekutif dan legislatif untuk memperbaiki tatanan pemerintahan. Tatanan pemerintahan yang ada saat ini, memberikan keleluasaan bagi terjadinya praktik korupsi dalam seluruh level pemerintahan. Perbaikan tatanan pemerintahan, menjadi kata kunci untuk membuat program penanggulangan kemiskinan benar-benar diperuntukkan bagi masyarakat miskin;

(10) Mendorong agenda pembangunan daerah memprioritaskan pemberantasan kemiskinan sebagai skala prioritas yang utama, mendorong tekad semua pihak untuk mengakui kegagalan penanggulangan kemiskinan selama ini, membangkitkan kesadaran kolektif agar memahami kemiskinan sebagai musuh bersama, dan meningkatkan partisipasi semua pihak dalam memberantas kemiskinan.

\section{Kesimpulan}

Konsep tentang kemiskinan sangat beragam, mulai dari sekadar ketidakmampuan memenuhi kebutuhan konsumsi dasar dan memperbaiki keadaan, kurangnya kesempatan berusaha, hingga pengertian yang lebih luas yang memasukkan aspek sosial dan moral.

Indikator utama kemiskinan adalah; (1) terbatasnya kecukupan dan mutu pangan; (2) terbatasnya akses dan rendahnya mutu layanan kesehatan; (3) terbatasnya akses dan rendahnya mutu layanan pendidikan; (4) terbatasnya kesempatan kerja dan berusaha; (5) lemahnya perlindungan terhadap aset usaha, dan perbedaan upah; (6) terbatasnya akses layanan perumahan dan sanitasi; (7) terbatasnya akses terhadap air bersih; (8) lemahnya kepastian kepemilikan dan penguasaan tanah; (9) memburuknya kondisi lingkungan hidup dan sumberdaya alam, serta terbatasnya akses masyarakat terhadap sumber daya alam; (10) lemahnya jaminan rasa aman; (11) lemahnya partisipasi; (12) besarnya beban kependudukan yang disebabkan oleh besarnya tanggungan keluarga; (13) tata kelola pemerintahan yang buruk yang menyebabkan inefisiensi dan inefektivitas dalam pelayanan publik, meluasnya korupsi dan rendahnya jaminan sosial terhadap masyarakat.

Syariat Islam memiliki banyak hukum yang berkaitan dengan pemecahan masalah kemiskinan; baik kemiskinan alamiyah, kultural, maupun sruktural. Islam mengatasi kemiskinan denga beberapa cara sebagai berikut: pertama, Jaminan Pemenuhan Kebutuhan Primer; kedua Pengaturan Kepemilikan; ketiga, Penyediaan Lapangan Kerja; dan Penyediaan Layanan Pendidikan. 


\section{Daftar Pustaka}

Abd. Rahman bin Muhammad 'Awadl al-Jaziriy, al-Fiqh 'ala Madzahib al-'Arba'ah. Mesir: Dar Ibn al-Haitsam, Tanpa Tahun.

Aji, Ahmad Mukri. Rasionalitas ijtihad Ibn Rusyd: kajian atas figh jinayat dalam kitab "Bidayat al-Mujtahid wa Nihayat al-Muqtashid, Bogor: Pustaka Pena Ilahi, 2010.

Aji, Ahmad Mukri; Yunus, Nur Rohim. Basic Theory of Law and Justice, Jakarta: Jurisprudence Institute, 2018.

Al-Raghib al-Ashfahaniy, Mu'jam Mufradat Alfazh al-Qur'an (Beirut: Dar al-Fkr, tanpa tahun.

Gregorius Sahdan, Menanggulangi Kemiskinan Desa, www.ekonomirakyat.org, Jurnal Ekonomi Rakyat.

Hukum Zakat, 2002. Cetakan keenam. Jakarta: Litera Antar Nusa

Kamus Besar Bahasa Indonesia, 1996. Edisi Kedua, Cetakan Ketujuh. Jakarta: Balai Pustaka

Lukman Ali et.all., Kamus Besar Bahasa Indonesia, Edisi Kedua, Cetakan Ketujuh, Jakarta: Balai Pustaka, 1996.

Maggalatung, A Salman. "Hubungan Antara Fakta Norma, Moral, Dan Doktrin Hukum Dalam Pertimbangan Putusan Hakim," dalam Jurnal Cita Hukum, Vol. 2, No. 2 (2014).

Masu'ah al-Hadis al-Syarif, Cetakan kedua, 2000 (Jami' al-Huquq Mahfudlah li Syirkah al-Baramij al-Islamiyah al-Dauliyah (Global IslamicSoftware Company), 1991-1997).

Masu'ah al-Hadis al-Syarif, Cetakan kedua, 2000 (Jami' al-Huquq Mahfudlah li Syirkah al-Baramij al-Islamiyah al-Dauliyah (Global IslamicSoftware Company), 1991-1997).

Nasikun. Diktat Mata Kuliah. Isu dan Kebijakan Penanggulangan Kemiskinan. Magister Administrasi Publik. Universitas Gadjah Mada, Yogyakarta. 2001.

Sayid Sabiq, Fikih Sunnah, Jilid I, Cetakan keempat, Bairut Lebanon: Dar al-Fikr, $1983 \mathrm{M} / 1403 \mathrm{H}$

Sunan Abu Dawud; 2539, Sunan Ibn Majah; 2829, Musnad Ahmad; 4266, 4920, $5603,5635,5753$.

Wahbah al-Zuhayli, al-Figh al-Islami wa Adillatuh, Cetakan keempat (Bairut Lebanon: Dar al-Fikr, 1997 M/1418 H), 1953.

www.bps.go.oid

Yafie, Ali. "Islam dan Problema Kemiskinan," Majalah Pesantren, No.2/VolIII/1986.

Yusuf Qardawi, Hukum Zakat, Cetakan keenam, Jakarta: Litera AntarNusa, 2002.

Zahrotunnimah, Zahrotunnimah; Yunus, Nur Rohim; Susilowati, Ida. "Rekonstruksi Teori Komunikasi Politik Dalam Membangun Persepsi Publik Pada Pemilihan Umum Presiden," dalam Jurnal Staatsrecht: Indonesian Constitutional Law Journal, Volume 2, Nomor 2 (2018). 